\title{
Peripheral B cells as reservoirs for persistent HCV infection
}

\author{
Masahiko Ito, Hideki Kusunoki and Toshiaki Mizuochi* \\ Department of Research on Blood and Biological Products, National Institute of Infectious Diseases, Tokyo, Japan \\ *Correspondence:miz@nih.go.jp
}

Hepatitis $\mathrm{C}$ virus (HCV) is an enveloped positive-stranded RNA virus of approximately $9.6 \mathrm{~kb}$ that belongs to the Flaviviridae family (Suzuki et al., 2007). HCV infection is a global health problem affecting nearly 200 million people (Lauer and Walker, 2001). The infection causes prolonged and persistent disease in over half of viral carriers that often leads to chronic hepatitis, cirrhosis, and hepatocellular carcinoma (Afdhal, 2004). Recent studies have suggested that HCV infects not only hepatocytes but also peripheral mononuclear lymphocytes, particularly B cells, which express CD81, a widely expressed tetraspanin molecule. CD81 has been shown to interact with the E2 region of HCV envelope proteins (Pileri et al., 1998) and is thus regarded as one of the key molecules involved in HCV infection. HCV infection of B cells is the likely cause of various B cell dysregulation disorders. Herein, we propose that HCV uses peripheral $\mathrm{B}$ cells as reservoirs for persistent infection, which are in turn responsible for HCV pathogenesis.

Although the liver is considered the primary and main target of HCV infection, extrahepatic manifestations such as mixed cryoglobulinemia, a systemic immune complex-mediated disorder characterized by $\mathrm{B}$ cell proliferation that may evolve into overt B cell non-Hodgkin's lymphoma (B-NHL), are often recognized among patients persistently infected with HCV (Agnello et al., 1992; Zuckerman et al., 1997). Epidemiological evidence strongly suggests a close association between chronic $\mathrm{HCV}$ infection and B-NHL occurrence (Turner et al., 2003; de Sanjose et al., 2008). A pathogenic role of $\mathrm{HCV}$ in $\mathrm{B}$ cell disorders has been further demonstrated by studies in which the clinical resolution of B cell dysfunctions was observed after successful regimens of anti-HCV treatment (Mazzaro et al., 1996; Agnello et al., 2002). Based on the aforementioned data, Antonelli et al. (2008) postulated a role of B cells in HCV pathogenesis. In accordance with this notion, our recent study clearly demonstrated that $\mathrm{HCV}$ infects and may replicate in the peripheral CD19 $\mathrm{B}$ cells of chronic hepatitis C (CHC) patients (Ito et al., 2010a). In order to determine how HCV evades antiviral innate immune responses that are normally induced in B cells, we analyzed expression levels of IFN- $\beta$ in peripheral B cells of CHC patients because type I IFN plays a critical role in the antiviral innate immune response. We found that $\mathrm{HCV}$ infection failed to trigger antiviral immune responses, such as IFN- $\beta$ production, in B cells of CHC patients (Ito et al., 2010b). This suggests that $\mathrm{HCV}$ evades antiviral innate immune responses in peripheral $\mathrm{B}$ cells and uses these cells as reservoirs for its persistent infection in the host.

The idea that B cells may serve as HCV reservoirs was advocated by Muller et al. (1993). Several subsequently published papers also favored the notion of $\mathrm{HCV}$ lymphotropism (Ducoulombier et al., 2004; Blackard et al., 2006; Pal et al., 2006). Figure 1 illustrates the possible process of $\mathrm{HCV}$ infection in $\mathrm{B}$ cells based on previous studies using human hepatocyte-derived cell lines (Burlone and Budkowska, 2009; Georgel et al., 2010). Among B cell subsets, memory B cells are assumed to be the main reservoirs of HCV infection primarily because of their long lifespans. In support of this notion, our recent study indicated that $\mathrm{CD} 19^{+} \mathrm{CD} 27^{+}$cells (i.e., memory B cell phenotype) express a high amount of CXCR3, a chemokine receptor, and are recruited to the inflammatory site in the liver of CHC patients where IFN$\gamma$-inducible protein-10, a CXCR3 ligand, is highly produced (Mizuochi et al., 2010; Figure 1). This unique strategy seems to

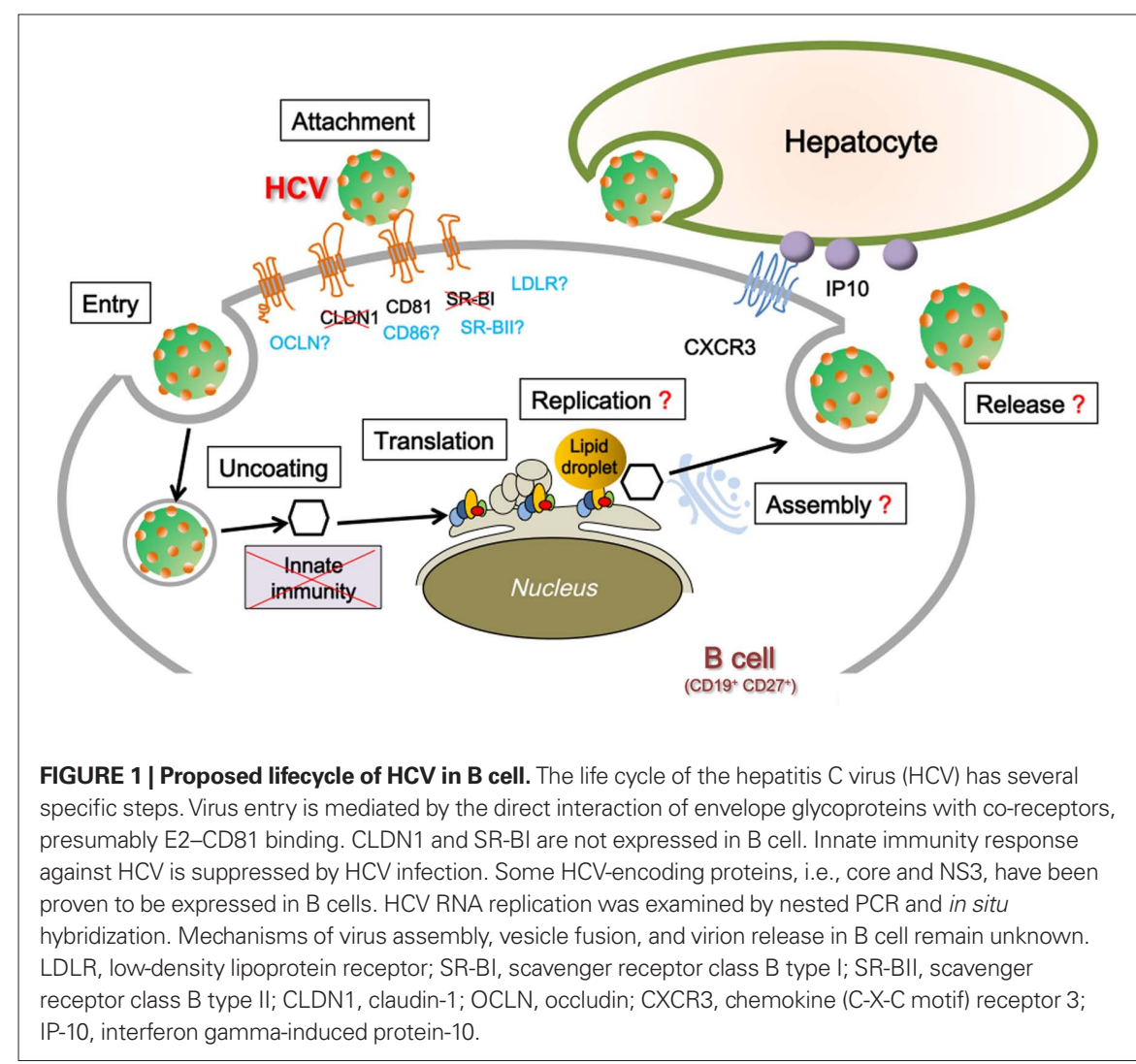


be beneficial for $\mathrm{HCV}$ in securing sites for persistent infection. HCV may search for reservoir sites in cellular compartments other than hepatocytes in case the liver becomes unsuitable for HCV replication, perhaps because of cellular destruction caused by the host immune response and/ or by irrelevant conditions for successful virus replication, such as the development of cirrhosis or hepatocellular carcinoma.

At least two important issues remain to be investigated. First, how do HCV-infected B cells evade "acquired/adaptive" immune responses represented by cytotoxic T cells (CTL)? In peripheral blood, the frequencies of $\mathrm{HCV}$-specific $\mathrm{CD}^{+}$lymphocytes with persistent $\mathrm{HCV}$ infection are lower than those with acute HCV infection. Furthermore, the CTL response to the $\mathrm{HCV}$ antigen is impaired in chronic HCV patients (Lechner et al., 2000). Interestingly, the percentage of CTL in peripheral blood is lower than that in the liver, which may be advantageous for persistent HCV infection in B cells. Because the peripheral B cells of $\mathrm{CHC}$ patients express the $\mathrm{HCV}$ core as well as NS3 antigens (Ito et al., 2010a), both of which encode functional CTL epitopes (Hiroishi et al., 2010), it is possible that $\mathrm{HCV}$-infected $\mathrm{B}$ cells are eliminated by CTL to some extent. However, the fact that substantial amounts of HCV-infected B cells are found in $\mathrm{CHC}$ patients suggests incomplete elimination by CTL by an inhibitory mechanism, i.e., HCV E2-mediated inhibition of IL-2/IFN- $\gamma$ secretion (Petrovic et al., 2011). Second, do HCV-infected B cells produce infectious HCV? Stamataki et al. (2009) demonstrated that the infectious JFH-1 strain of HCV can bind B cells but fails to establish productive infection. On the other hand, Inokuchi et al. (2009) recently demonstrated the presence of negative-stranded HCV RNA, a marker of viral replication, in B cells from 4 of 75 (5\%) $\mathrm{CHC}$ patients. These results support the notion that HCV replicates in B cells and suggest that infectious HCV are produced in B cells. We have currently been investigating this intriguing issue by using an in vitro assay system.

In conclusion, lymphoid reservoirs of HCV infection may play a role in viral persistence and thereby be involved in its pathogenesis. Infection and replication of HCV in peripheral B cells should be regarded as a considerable impediment to the treatment of $\mathrm{CHC}$ patients undergoing various antiviral regimens. From a therapeutic viewpoint, it may be beneficial to eliminate peripheral $\mathrm{B}$ cells in $\mathrm{CHC}$ patients by administering anti-B cell antibodies, such as rituximab, along with combination chemotherapy of peg-IFN- $\alpha$ and ribavirin, which eliminate circulating HCV in the blood. Together, this could lead to a synergistic effect on $\mathrm{HCV}$ clearance in $\mathrm{CHC}$ patients.

\section{ACKNOWLEDGMENTS}

This work was supported by Grants-in-Aid from the Ministry of Health, Labour, and Welfare, Japan.

\section{REFERENCES}

Afdhal, N. H. (2004). The natural history of hepatitis C. Semin. Liver Dis. 24(Suppl. 2), 3-8.

Agnello, V., Chung, R. T., and Kaplan, L. M. (1992). A role for hepatitis $\mathrm{C}$ virus infection in type II cryoglobulinemia. N. Engl. J. Med. 327, 1490-1495.

Agnello, V., Mecucci, C., and Casato, M. (2002). Regression of splenic lymphoma after treatment of hepatitis C virus infection. N. Engl. J. Med. 347, 2168-2170.

Antonelli, A., Ferri, C., Galeazzi, M., Giannitti, C., Manno, D., Mieli-Vergani, G., Menegatti, E., Olivieri, I., Puoti, M., Palazzi, C., Roccatello, D., Vergani, D., Sarzi-Puttini, P., and Atzeni, F. (2008). HCV infection: pathogenesis, clinical manifestation and therapy. Clin. Exp. Rheumatol. 26(Suppl. 48), S39-S47.

Blackard, J. T., Kemmer, N., and Sherman, K. E. (2006). Extrahepatic replication of HCV: insights into clinical manifestations and biological consequences. Hepatology 44, 15-22.

Burlone, M. E., and Budkowska, A. (2009). Hepatitis C virus cell entry: role of lipoproteins and cellular receptors. J. Gen. Virol. 90, 1055-1070.

de Sanjose, S., Benavente, Y., Vajdic, C. M., Engels, E. A., Morton, L. M., Bracci, P. M., Spinelli, J. J., Zheng, T., Zhang, Y., Franceschi, S., Talamini, R., Holly, E. A., Grulich, A. E., Cerhan, J. R., Hartge, P., Cozen, W., Boffetta, P., Brennan, P., Maynadie, M., Cocco, P., Bosch, R., Foretova, L., Staines, A., Becker, N., and Nieters, A. (2008). Hepatitis C and non-Hodgkin lymphoma among 4784 cases and 6269 controls from the International Lymphoma Epidemiology Consortium. Clin. Gastroenterol. Hepatol. 6, 451-458.

Ducoulombier, D., Roque-Afonso, A. M., Di Liberto, G., Penin, F., Kara, R., Richard, Y., Dussaix, E., and Feray, C. (2004). Frequent compartmentalization of hepatitis $C$ virus variants in circulating $B$ cells and monocytes. Hepatology 39, 817-825.

Georgel, P., Schuster, C., Zeisel, M. B., Stoll-Keller, F., Berg, T., Bahram, S., and Baumert, T. F. (2010). Virus-host interactions in hepatitis $\mathrm{C}$ virus infection: implications for molecular pathogenesis and antiviral strategies. Trends Mol. Med. 16, 277-286.

Hiroishi, K., Eguchi, J., Ishii, S., Hiraide, A., Sakaki, M., Doi, H., Omori, R., and Imawari, M. (2010). Immune response of cytotoxic $\mathrm{T}$ lymphocytes and possibility of vaccine development for hepa- titis C virus infection. J. Biomed. Biotechnol. doi: $10.1155 / 2010 / 263810$

Inokuchi, M., Ito, T., Uchikoshi, M., Shimozuma, Y., Morikawa, K., Nozawa, H., Shimazaki, T., Hiroishi, K., Miyakawa, Y., and Imawari, M. (2009). Infection of $B$ cells with hepatitis $C$ virus for the development of lymphoproliferative disorders in patients with chronic hepatitis C. J. Med. Virol. 81, 619-627.

Ito, M., Murakami, K., Suzuki, T., Mochida, K., Suzuki, M., Ikebuchi, K., Yamaguchi, K., and Mizuochi, T. (2010a). Enhanced expression of lymphomagenesis-related genes in peripheral blood B cells of chronic hepatitis C patients. Clin. Immunol. 135, 459-465.

Ito, M., Masumi, A., Mochida, K., Kukihara, H., Moriishi, K., Matsuura, Y., Yamaguchi, K., and Mizuochi, T. (2010b). Peripheral B cells may serve as a reservoir for persistent hepatitis $\mathrm{C}$ virus infection. J. Innate Immun. 2, 607-617.

Lauer, G. M., and Walker, B. D. (2001). Hepatitis C virus infection. N. Engl. J. Med. 345, 41-52.

Lechner, F., Wong, D. K., Dunbar, P. R., Chapman, R., Chung, R. T., Dohrenwend, P., Robbins, G., Phillips, R., Klenerman, P., and Walker, B. D. (2000). Analysis of successful immune responses in persons infected with hepatitis C virus. J. Exp. Med. 191, 1499-1512.

Mazzaro, C., Franzin, F., Tulissi, P., Pussini, E., Crovatto, M., Carniello, G. S., Efremov, D. G., Burrone, O., Santini, G., and Pozzato, G. (1996). Regression of monoclonal B-cell expansion in patients affected by mixed cryoglobulinemia responsive to alpha-interferon therapy. Cancer 77, 2604-2613.

Mizuochi, T., Ito, M., Saito, K., Kasai, M., Kunimura, T., Morohoshi, T., Momose, H., Hamaguchi, I., Takai, K., Iino, S., Suzuki, M., Mochida, S., Ikebuchi, K., and Yamaguchi, K. (2010). Possible recruitment of peripheral blood CXCR3+ CD27+CD19+ B cells to the liver of chronic hepatitis $\mathrm{C}$ patients. J. Interferon Cytokine Res. 30, 243-252.

Muller, H. M., Pfaff, E., Goeser, T., Kallinowski, B., Solbach, C., and Theilmann, L. (1993). Peripheral blood leukocytes serve as a possible extrahepatic site for hepatitis C virus replication. J. Gen. Virol. 74(Pt 4), 669-676.

Pal, S., Sullivan, D. G., Kim, S., Lai, K. K., Kae, J., Cotler, S. J. Carithers, R. L.Jr., Wood, B.L., Perkins, J.D., and Gretch, D. R. (2006). Productive replication of hepatitis $C$ virus in perihepatic lymph nodes in vivo: implications of HCV lymphotropism. Gastroenterology 130,1107-1116.

Petrovic, D., Stamataki, Z., Dempsey, E., Golden-Mason, L., Freeley, M., Doherty, D., Prichard, D., Keogh, C., Conroy, J., Mitchell, S., Volkov, Y., McKeating, J. A., O'Farrelly, C., Kelleher, D., and Long, A. (2011). Hepatitis $\mathrm{C}$ virus targets the $\mathrm{T}$ cell secretory machinery as a mechanism of immune evasion. Hepatology 53, 1846-1853.

Pileri, P., Uematsu, Y., Campagnoli, S., Galli, G., Falugi, F., Petracca, R., Weiner, A. J., Houghton, M., Rosa, D., Grandi, G., and Abrignani, S. (1998). Binding of hepatitis C virus to CD81. Science 282, 938-941.

Stamataki, Z., Shannon-Lowe, C., Shaw, J., Mutimer, D., Rickinson, A. B., Gordon, J., Adams, D. H., Balfe, P., and McKeating, J.A. (2009). Hepatitis C virus association with peripheral blood $\mathrm{B}$ lymphocytes potentiates viral infection of liver-derived hepatoma cells. Blood $113,585-593$.

Suzuki, T., Ishii, K., Aizaki, H., and Wakita, T. (2007). Hepatitis C viral life cycle. Adv. Drug Deliv. Rev. 59, 1200-1212. 
Turner, N. C., Dusheiko, G., and Jones, A. (2003). Hepatitis C and B-cell lymphoma. Ann. Oncol. 14, 1341-1345.

Zuckerman, E., Zuckerman, T., Levine, A. M., Douer, D., Gutekunst, K., Mizokami, M., Qian, D. G., Velankar, M., Nathwani, B. N., and Fong, T. L. (1997). Hepatitis Cvirus infection in patients with B-cell non-Hodgkin lymphoma. Ann. Intern. Med. 127, 423-428.
Received:04 July 2011; accepted: 11 August 2011; published online: 31 August 2011.

Citation: Ito M, Kusunoki $H$ and Mizuochi $T$ (2011) Peripheral B cells as reservoirs for persistent HCV infection. Front. Microbio. 2:177. doi: 10.3389/fmicb.2011.00177 This article was submitted to Frontiers in Virology, a specialty of Frontiers in Microbiology.
Copyright (๑) 2011 Ito, Kusunoki and Mizuochi. This is an open-access article subject to a non-exclusive license between the authors and Frontiers Media SA, which permits use, distribution and reproduction in other forums, provided the original authors and source are credited and other Frontiers conditions are complied with. 